\title{
Kurikulání reforma na gymnáziích: rozhovory s koordinátory
}

\section{Curricular reform grammar schools: interviews with coordinators}

\author{
Tomáš Janík, Petr Knecht, David Solnička
}

\begin{abstract}
Anotace: Př́íspěvek představuje koncepci výzkumu Kvalitní škola, který byl zaměřen na kurikulární reformu na gymnáziích, a dále metodický postup a vybrané výsledky jeho první fáze. Ta byla realizovaná formou řízených rozhovorů s koordinátory tvorby školních vzdělávacích programů na pilotních gymnáziích. Cílem výzkumu v této fázi bylo zachycení kurikulární reformy jako komplexu zahrnujícího řadu problémových okruhů (ideje a cíle kurikuální reformy, implementace kurikulární reformy, podpora reformy, reforma a možnosti rozvoje a profilace školy, učitel a kurikulární reforma, tvorba ŠVP vstupovaly a vliv dalších kurikulárních materiálů, ŠVP a realizace výuky, klíčové kompetence, autoevaluace a evaluace), které byly dále podrobněji zkoumány v dalších fázích výzkumu.
\end{abstract}

Klíčová slova: kurikulární reforma, gymnázia, výzkum

\begin{abstract}
The text presents the design of the research project Kvalitní škola that was aimed at the current curricular reform in Czech upper-secondary comprehensive schools. It also presents the methodology and selected results of the first phase of the project, which was realised through a series of interviews with coordinators of School educational program development on pilot schools. This first phase aimed on capturing the curricular reform as a complex of various problem issues (aims of curricular reform, implementation of curricular reform, supporting the reform, possibilities of school development within the reform, teachers within the reform, developing the School education program, instruction within the reform, key competences, evaluation and autoevaluation), which were further analysed in the subsequent phases of the project.
\end{abstract}

Keywords: curricular reform, upper-secondary comprehensive school, research

\section{$1 \quad$ Úvodem}

Výzkumný tým z Institutu výzkumu školního vzdělávání Pedagogické fakulty Masarykovy univerzity byl přizván, aby $\mathrm{v}$ rámci projektu Kurikulum $\mathrm{G}$ realizoval výzkum kurikulární reformy na gymnáziích. Připravili jsme výzkumný projekt s názvem Kvalitní škola a přistoupili jsme k jeho realizaci. Náš aktuální problém spočívá v tom, že intervaly mezi jednotlivými reformami se $\mathrm{v}$ posledních letech zkracují, přičemž tempo jejich zavádění narůstá.

Na úvod několik slov k tomu, jakou roli by mohl sehrávat výzkum ve vztahu ke vzdělávání. Přibližně od 70. let 20. století se ve vyspělých evropských zemích prosazuje ideálně typická představa, že problémy vzdělávání budou výzkumně analyzovány a na tomto základě budou činěna kvalifikovaná politická rozhodnutí stran nejrůznějších opatření. Tato opatření mají mít nejprve podobu tzv. experimentálních programů, přičemž se má ověřovat jejich potenciál pro 
řešení daných problémů. Experimentálni programy, pokud se osvědčí, mají být jako programy modelové přenášeny do celého systému.

S přihlédnutím k poslednímu vývoji se zdá, že uvedená představa není ani tak ideálně typická jako spíše naivně romantická. Je totiž založena na technokratické představě o racionalizovatelnosti společensko-politických procesů; na víře, že věda bude schopna identifikovat problémy a nabízet jejich řešení; na důvěře $\mathrm{v}$ racionalitu politického rozhodování atp. (srov. Terhart, 2002, s. 123-124).

Přesto se objevují nové a nové pokusy o vytváření mostů mezi výzkumem vzdělávání, vzdělávací politikou a reformou vzdělávání. Z rozboru, který předložila Rada Evropy počátkem 90 . let 20. století, vyplývá, že vztah mezi uvedeným může nabývat tří základních variant:

1. Za příznivých podmínek výzkum vytvárí poznatkový fond, tj. databázi, kterou školská správa může využít při rozhodování o reformách a inovacích.

2. Za méně př́iznivých podmínek jsou reformy zaváděny bez předcházejícího výzkumu a experimentace, ale při jejich realizaci se pečlivě sleduje (monitoring) a hodnotí (evaluace) vše, čeho je dosaženo. Ze zjištěných výsledků se vyvozují závěry.

3. Při zcela nepř́znivých podmínkách se změny vzdělávacího systému uskutečňují centrálním rozhodnutím s výrazně politickou motivací, bez předchozího zapojení výzkumu a vývoje. Nedochází $\mathrm{k}$ myšlenkovému a názorovému kontaktu mezi školskými politiky, výzkumníky a učiteli. Dochází pak k častým změnám v koncepci reformy, organizačním nedůslednostem (Kotásek, 1993, s. 368).

Zdá se, že naši současnou situaci by nejpřiléhavěji charakterizoval model $3 \mathrm{~s}$ určitým přesahem k modelu 2. Model 1 je v nedohlednu, avšak bylo by možné $\mathrm{k}$ němu směřovat za předpokladu, že by MŠMT vytvořilo ucelenou koncepci resortního výzkumu vzdělávání. $\mathrm{V}$ tomto př́padě by mohl výzkum plnit důležité úlohy ve vztahu ke vzdělávací politice. $\mathrm{V}$ explanačním pojetí je úlohou výzkumu objevování problémů $\mathrm{v}$ edukační realitě $\mathrm{s}$ cílem navrhovat modifikace stávajících edukačních programů. V normativním pojetí je úlohou výzkumu mapovat uplatňování programů v praxi, čímž může výzkum nepřímo podporovat vývoj k očekávanému stavu edukační reality (Slavík \& Chvál, 2008). Z uvedeného vyplývá, že našemu týmu je blízké chápání výzkumu jakožto kritického přítele kurikulární reformy. Přistupme nyní $\mathrm{k}$ tomu, že představíme východiska, pojetí a cíle námi realizovaného výzkumu Kvalitní škola.

\section{Východiska výzkumu Kvalitní škola}

Co se týče našich výchozích úvah, podstatné je uvědomění si skutečnosti, že v aktuální fázi kurikulární reformy na gymnáziích je klíčovým proces implementace, tj. zavádění rámcového vzdělávacího programu, který ústí do tvorby a realizace školních vzdělávacích programů. Zahraniční výzkumy (Altrichter \& Wiesingerová, 2005) ukazují, že většina prostředků a energie je věnována tvorbě nových (např. kurikulárních) koncepcí. Tvorba totiž navenek nejvýrazněji signalizuje politicko-administrativní aktivitu. Naproti tomu implementace těchto nových koncepcí je často upozaděna, nebot' se jedná o méně evidentní, o to však náročnější aktivity spojené s péčí o postoje klíčových osob, s konkrétní podporou procesu implementace $\mathrm{v}$ často konfliktním ovzduší apod. Implementace má přitom zásadní význam z hlediska dopadu reformních idejí do školské praxe. Podcenit implementaci znamená vystavit se riziku, že reformní ideje se do praxe očekávaným způsobem nepromítnou. 
Právě na podporu implementace jsou zaměřeny aktivity projektu Kurikulum $G$ a výzkumu Kvalitní škola. Nabízí se otázka, jak může výzkum podporovat implementaci. Nejspíše tím, že přináší odpovědi na otázky stojící v pozadí kurikulární reformy. Umožňuje dobrat se hlubšího porozumění problémům, jež jsou s reformou kurikula spojeny.

Realizace takového výzkumu předpokládá vytvoření teoretického rámce, který by umožňoval položit si relevantní výzkumné otázky. V našem výzkumu pracujeme s rozlišením dvou hlavních, zastřešujících pojmů: kurikulární procesy a formy existence kurikula.

- Projektování (tvorba) kurikula spočívá v rozpracování cílů a obsahů vzdělávání do konkrétních kurikulárních dokumentů - výsledkem je projektované kurikulum.

- Implementace kurikula spočívá v zavádění kurikulárních dokumentů do škol výsledkem je implementované kurikulum.

- Realizace kurikula spočívá ve zprostředkovávání kurikulárních cílů a obsahů žákům výsledkem je realizované kurikulum.

- Osvojování kurikula spočívá ve zvnitřňování kurikulárních cílů a obsahů žáky výsledkem je dosažené (osvojené) kurikulum.

- Revize kurikula spočívá v zavádění změn do projektovaného kurikula - výsledkem je revidované projektované kurikulum.

Uvedené rozlišení umožňuje položit si otázku, jakými adaptacemi prochází kurikulární dokument na cestě od své ideové koncepce přes své uskutečnění až k revizi.

Cílem výzkumu Kvalitní škola je popsat, vysvětlit a vyhodnotit procesy implementace RVP a tvorby a realizace ŠVP. Přitom mají být identifikovány faktory ovlivňující tyto procesy a dále funkce, které jsou prostřednictvím RVP/ŠVP naplňovány v rovině kurikulárního plánování a $\mathrm{v}$ rovině práce $\mathrm{s}$ cíli a obsahy vzdělávání.

Výzkum je zde prostředkem, který na základě (1) komplexního popisu situací v edukační realitě ústí do (2) vysvětlování souvislostí a důvodů zjištěného stavu reality, a konečně do (3) systematického hodnotícího porovnávání reálného stavu s jeho předpokládanými lepšími variantami. V tomto pojetí naplňuje výzkum funkci popisnou, vysvětlující a hodnotící.

Pilotní fáze výzkumu je realizována na přelomu let 2009/2010, hlavní šetření probíhalo v letech 2010-2011 a bylo rozvrženo do pěti fází, v nichž byly využívány a kombinovány kvantitativní a kvalitativní výzkumné přístupy a metody:

1. ̌̌ízené rozhovory byly vedeny s řediteli a učiteli (koordinátory tvorby ŠVP) na pilotních $(\mathrm{n}=19)$ i nepilotních $(\mathrm{n}=6)$ gymnáziích. Jejich cílem bylo dokumentovat proces vzniku ŠVP a porozumět problémům, které jsou s tvorbou kurikula ve školách spojeny (Janík et al., 2010a; Janík, Najvar, \& Solnička, 2011).

2. Dotazníkové šetření bylo realizováno na reprezentativním souboru gymnázií a zaměřovalo se na ředitele a na učitele $(\mathrm{n}=1098)$. Jeho cílem bylo prozkoumat akceptaci kurikulární reformy, pojetí kurikula a vnímanou využitelnost a účinnost ŠVP (Janík et al., 2010b).

3. Formou případových studií byly zkoumány jak samotné texty ŠVP, tak procesy jejich vzniku. Cílem bylo popsat roli učitele jako tvůrce kurikula a získat náhled na vztahy mezi jazykem teorie, jazykem kurikulárních dokumentů a učiteli běžně užívaným jazykem praxe. Př́ípadové studie byly realizovány v osmi oborech gymnaziálního vzdělávání; zapojilo se do nich celkem 10 učitelů (Píšová, Kostková, \& Janík et al., 2011). 
4. Prostřednictvím videostudií byly zkoumány příležitosti, které reálná výuka nabízí pro rozvíjení žákovských kompetencí. Výzkumné a teoretické pojetí videostudií se stalo východiskem pro další rozpracování metodiky virtuálních hospitací s cílem analyzovat kvalitu procesu výuky ve smyslu realizovaného kurikula (Janík, Slavík, \& Najvar et al., 2011).

5. Závěrečné expertní šetření bylo zaměřeno na kvalitu školy a kurikula z pohledu zkušených gymnaziálních ředitelů a učitelů $(n=57)$. Jeho těžiště spočívalo ve vypracování empiricky založených východisek pro tvorbu standardu kvality školy a kurikula (Janík et al., 2011).

Z uvedeného schématu je patrné, že problematika kurikula je sledována v systémovém pohledu, který zahrnuje makrorovinu (školství), mezorovinu (škola) a mikrorovinu (výuka). Dále je zřejmé, že nejdříve se bude zkoumat chápání reformy v obecné rovině, což bude východiskem $\mathrm{k}$ tomu, aby se následně zkoumalo chápání reformy $\mathrm{v}$ rámci vybraných oblastí či oborů gymnaziálního vzdělávání. Aktivity navazující na výzkum ve fázích $1-5$ směřují $\mathrm{k}$ rozpracování kritérií a indikátorů pro hodnocení kvality školy a kurikula.

\section{$3 \quad$ Metodický postup}

Na tomto místě představujeme výsledky první fáze výzkumu, která byla založena na řízených rozhovorech. Posláním rozhovorů nebylo ani tak samotné získání či ověření výzkumných poznatků, jako spíše získání vhledu a orientace ve sledované problematice. Rozhovory byly vedeny s koordinátory tvorby ŠVP, popř. s řediteli na pilotních a partnerských gymnáziích. Jednalo se o záměrný výběr, $\mathrm{v}$ němž byla zahrnuta pilotní gymnázia ( $15 \mathrm{z}$ původního počtu 16) a dále 4 partnerská gymnázia. Prvotně šlo o zachycení pohledu koordinátorů tvorby ŠVP. Pohledy jiných aktérů (ředitelů, učitelů) byly zachyceny pouze zprostředkovaně. Rozhovor byl veden tak, že $\mathrm{k}$ sledované tematické oblasti byla respondentům položena hlavní otázka (Popište, jak...) a byl poskytnut prostor pro volnou výpověd'. Poté byly kladeny další doplňující otázky. Rozhovory zachycené na audiozáznam byly přepsány do textové podoby a postoupeny dalšímu zpracování $\mathrm{v}$ software MAX QDA. V tomto programu probíhalo kódování $\mathrm{v}$ rámci kvalitativní obsahové analýzy. Výsledky jsme zpracovali do podoby „př́íběhu kurikulární reformy“ (Janík et al., 2010a).

\section{$4 \quad$ Vybrané výsledky a diskuse}

Náš pokus o zachycení kurikulární reformy jako komplexního problému zahrnujícího celou řadu aspektů nabývá této podoby. Mapa zachycuje ,,př́běh kurikulární reformy“ včetně jeho rozpisu do trojúrovňového systému školství - škola - výuka. V dalším výkladu budu postupovat tak, že budu procházet jednotlivá témata prríběhu kurikulární reformy. Při každém z nich uvedeme hlavní výzkumná zjištění a připojíme jejich diskusi.

\subsection{Ideje a cíle kurikuální reformy}

$\mathrm{V}$ celkovém pohledu je reforma vnímána jako možnost pro uskutečnění širokého spektra změn vztahujících se $\mathrm{k}$ profilaci školy, $\mathrm{k}$ cílové orientaci vzdělávacích oblastí a oborů, $\mathrm{k}$ výběru a uspořádání vzdělávacích obsahů, $\mathrm{k}$ metodám a formám výuky. Zdá se, že dominantní je vnímání reformy jako př́ležitosti pro změny v oblasti výukových metod, přičemž důraz je kladen na metody aktivizující (činnostní učení). Téma změny školy jako 
instituce a jejich funkcí - personalizační, socializační, enkulturační - bylo v rozhovorech reflektováno pouze $\mathrm{v}$ náznacích. Poukazovalo se na to, že kurikulární reforma se opírá o pojmy (kurikulum, autonomie, klíčové kompetence), jejichž výklad může být poměrně široký. Uvedené pojmy nejsou jednoznačně chápány, proto není snadné dobrat se sdíleného porozumění tomu, o co v reformě jde především a jak k tomu směřovat.

Z jiných výzkumů víme (Straková, 2007), že chybí obecné povědomí o tom, v čem spočívají hlavní problémy školního vzdělávání v naší zemi. Zejména mezi laickou veřejností převládá spokojenost s jeho úrovní. Není tudíž jasné, jaký je ten hlavni problém, jenž má být kurikulární reformou (vy)řešen. V tomto ohledu se české reformní snahy liší např. od současného reformního úsilí v Německu či Rakousku. V těchto zemích je potřeba změn zdůvodňována jedním zásadním, široce srozumitelným a bezpochyby pádným argumentem. Jsou jím nedobré výsledky žáků v mezinárodně srovnávacích studiích TIMSS a PISA. Na okraj nutno dodat, že zatímco v Německu či Rakousku se směřuje spíše k centralizaci a standardizaci kurikula, v České republice je aktuálním vývojovým trendem decentralizace a autonomizace. Bude nanejvýš zajímavé sledovat další domácí vývoj v této oblasti.

\subsection{Implementace kurikulární reformy}

Z rozhovorů vyplývá, že $\mathrm{v}$ př́padě pilotních a partnerských gymnázií se do jisté míry daří propojovat inovativní úsilí škol, které vyrůstá zespoda, s reformováním vedeným shora. $\mathrm{V}$ procesu implementace je angažována řada institucí a aktérů, přičemž se poukazovalo na nejasnosti v tom, kdo má v reformě sehrávat jaké role. Někteří respondenti se nemohli ubránit dojmu, že při zavádění reformy nejsou systémově koordinovány aktivity jednotlivých ministerských institucí. Jako by každá ze zúčastněných institucí (VÚP, ČŠ́, CERMAT) disponovala jiným výkladem reformy a jejich cílů. Za zásadní byl považován problém nesouladu mezi znalostním pojetím katalogu maturitních požadavků a kompetenčním pojetím v Rámcových vzdělávacích programech.

Jakkoliv školské reformy zpravidla začínají jako vedené shora dolů, v průběhu implementace se jejich nositelství rozšiřuje na další a další aktéry. Postupně se tak v reformě začínají angažovat různí zvaní i nezvaní hosté, z nichž někteří ji pojímají jako prostor pro realizaci vlastních „podnikatelských“ či jiných záměrů. A tak se může stát, že reforma nabude v průběhu implementace podoby, v níž ji ti, kteří ji uváděli do života, už vůbec nepoznají (Altrichter, 2009). Pupala (2008) v této souvislosti hovoří o mocenských poutech reformy. Upozorňuje na to, že bude-li reforma zmítána různými střety zájmů, může být oslabeno její hlavní cílové zaměření. Na možné střety zájmů se $\mathrm{v}$ našich rozhovorech poukazuje pouze $\mathrm{v}$ náznacích. Tu a tam je vedle toho vyjadřován pocit, že zde někdo někoho supluje...

$\mathrm{V}$ zahraničních výzkumech se dospělo $\mathrm{k}$ důležitému poznatku. Má-li být implementace úspěšná, je nezbytné, aby se na důležitých rozhraních systému utvořily nové instituce, jež by měly odpovídající mandát a fungovaly by průřezově. Jejich úlohou je držet pohromadě různé aktéry na různých úrovních a koordinovat jejich aktivity $\mathrm{v}$ zájmu dosahování nadřazených cílů (srov. Altrichter, 2009).

\subsection{Podpora reformy}

Za jeden z problémů je považována nízká informovanost širší veřejnosti o probíhajících změnách a jejich důvodech. Silnější mediální podpora by podle koordinátorů mohla vést $\mathrm{k}$ vyšší zainteresovanosti rodičů i dalších aktérů. Finanční podpora je rovněž chápána jako 
problematická. Finančních prostředků se podle koordinátorů nedostává v oblasti materiální vybavenosti škol a v oblasti odměňování učitelů. Zatímco pedagogické sbory pilotních školy byly $\mathrm{v}$ rámci možností finančně odměňovány, na nepilotních školách je reforma vnímána jako „spousta nezaplacené práce navíc“.

Nejvíce komentář̉ v této oblasti se týkalo metodické podpory učitelů vytvářejících ŠVP. Na adresu vysokých škol a dalšího vzdělávání učitelů zaznívala kritika: fakulty v př́ípravě učitelů nevěnují reformě dostatek pozornosti a další vzdělávání $\mathrm{v}$ krajích není dostatečně systematické a efektivní. Aktivity organizované VÚP byly oproti tomu hodnoceny převážně kladně, i když nelze vyloučit pozitivní zkreslení dané úzkou součinností respondentů $\mathrm{s}$ pracovníky VÚP.

Jako samostatné téma vykrystalizovala problematika evaluace učitelova profesního výkonu, která je také spojena s řadou nejasností a kritických míst. Se značnými obavami je vnímán nárůst administrativy a formalismu, jež jsou s reformováním spojeny.

\subsection{Reforma a možnosti rozvoje a profilace školy}

Pilotní a partnerská gymnázia představují specifickou skupinu škol, na nichž byly různé pedagogické inovace realizovány již před reformou. Výzkum naznačuje, že na těchto školách je možnost tvorby školních vzdělávacích programů vnímána jako př́ležitost pro legitimizaci, popřr. rozvinutí či zdůraznění toho, oč již dřive usilovaly.

V rozhovorech se odkazuje k možnosti využití ŠVP jako prostředku profilace školy. Na jedné straně je profilace vnímána jako prostředek k odlišení konkrétní školy od jiných škol, tj. zdůraznění její jinakosti. Na druhé straně stojí profilace, jejímž cílem patrně nebylo v první řadě odlišení, ale formulace společného cíle školy - tj. určité mise směrem ke společnosti, ve které škola funguje. V této souvislosti bylo zdůrazňováno zaměření na všeobecnou vzdělanost.

O možných změnách v pojetí gymnaziálního vzdělávání můžeme uvažovat na pozadí výsledků výzkumu Walterové et al. (2010), který se zaměřoval na názory veřejnosti na vzdělávání. Ukazuje se, že téměř polovina populace (46 \%) považuje za ideální vzdělávací dráhu pro své děti střední odbornou školu. Jak se uvádí v citovaném výzkumu: „Jde o volbu, která umožňuje relativně dobré uplatnění absolventa na trhu práce, avšak zároveň představuje jednu z možností, jak dále pokračovat ve studiu na vyšší odborné či vysoké škole, kdy je jako podmínka vyžadována maturitní zkouška. Dále jsou favorizována odborná učiliště; jejich vystudování by pro své děti preferovala téměř třetina veřejnosti (29 \%), avšak v tomto př́ipadě nejlépe učební obor zakončený maturitou ( $22 \%$ všech respondentů)“. O něco méně než předchozí vzdělávací dráhy jsou pak preferována gymnázia - s $23 \%$.

V souvislosti s tím se otevírá otázka, zda do budoucna očekávat větší rozrůzněnost gymnázií na kontinuu „Všeobecně vzdělávací - specializované““ a jakou roli v tom budou sehrávat ŠVP jako nástroje profilace školy. Jak bude reagovat vzdělávací politika v př́ípadě, že by pragmatická reakce na „ruku trhu“ hrozila odklonem od všeobecně vzdělávacího zaměření gymnázií?

\subsection{Učitel a kurikulární reforma}

Mezi klíčová témata lze řadit aktuální složení pedagogických sborů, které je vnímáno jako jeden z důležitých faktorů reformy. Zdá se, že nezbytnost spolupráce učitelů při tvorbě ŠVP a 
potřeba spolupráce vyvolaná novými možnostmi v RVP (průřezová témata, vzdělávací oblasti, projekty) podnítila ve sborech živější profesionální komunikaci, která zřejmě přispěla k proreformnímu úsilí. Svoji roli nejen sehrávala míra proreformního přesvědčení jednotlivých učitelů, ale i věk a zkušenosti učitelů s předešlými reformami. Mezi rozhodující vlivy se řadil i postoj vedení školy. Otevřenou zůstává otázka doby životnosti nastalých změn. Vyhodnotit, zda se určitá část učitelů po odeznění reformní euforie (či povinnosti) vrátila $\mathrm{k}$ tradičním vyučovacím postupům, je úkolem pro další výzkum.

Jako zajímavé se ukázalo téma ,pohyb učitelů mezi školami“. Jak bylo naznačeno v rozhovorech a jak se ukazuje v probíhajícím dotazníkovém šetření, v důsledku nesouhlasu se změnami a způsobem jejich zavádění se někteří učitelé dávají do pohybu. Odchod učitele z pilotní školy jako důsledek nesouhlasu s reformou však řeší situaci pouze ve fázi pilotáže. Navíc - pokud předpokládáme, že učitelé odchází na nepilotní školy, nikoli mimo školství se tím snižuje pravděpodobnost akceptace reformy na ostatních školách. Či snad, až dolehne reforma na tyto ostatní školy, bude neztotožnění se s reformou znamenat pro učitele definitivní odchod ze školství? Domníváme se, že fenomén, s nímž se zde setkáváme, jde nad rámec toho, co je v literatuře označováno jako „rezistence vůči změně“ (Lazarová, 2005).

Z předběžných výsledků právě probíhajícího dotazníkového šetření ke kurikulární reformě zatím víme, že na gymnáziích panuje určitý neklid a nespokojenost s vývojem a stavem školství. Z přibližně 1000 gymnaziálních učitelů pouhých 71 (cca. 7 \%) uvedlo, že jsou určitě či spíše spokojeni s vývojem českého školství v posledních 5 letech. Naproti tomu 763 učitelů (cca. $78 \%$ ) odpovědělo, že jsou určitě či spíše nespokojeni s vývojem českého školství $\mathrm{v}$ posledních 5 letech.

\subsection{Tvorba ŠVP vstupovaly a vliv dalšich kurikulárních materiálů}

Co se týče vlivu jednotlivých kurikulárních dokumentů na tvorbu ŠVP, je nutné upozornit především na klíčovou roli RVP G. Tento dokument nejenže výraznou měrou ovlivňoval výslednou koncepci a podobu ŠVP, ale do jisté míry také podněcoval diskuzi mezi učiteli na školách. V této diskuzi si učitelé ujasňovali např. otázky týkající se mezipředmětových vztahů nebo časové dotace jednotlivých vyučovacích předmětů. V rozhovorech byla zmiňována nezanedbatelná úloha dřívějších osnov, jejichž obsah se často do ŠVP také promítal. Někteří učitelé mají zřejmě obsah dřivějších osnov dlouhodobě uložen ve své paměti, což může ovlivňovat jejich představy o obsahové skladbě výuky.

Co se týče vlivu učebnic na podobu ŠVP, je možné pozorovat výrazné rozdíly mezi jednotlivými gymnázii i mezi vzdělávacími oblastmi či obory. Zatímco některá gymnázia obsah ŠVP výrazně přizpůsobila obsahu učebnic, na jiných gymnáziích obsah učebnic výrazněji výslednou podobu ŠVP neovlivnil. Z dalších kurikulárních dokumentů, které učitelé používali během tvorby ŠVP, je možné zmínit RVP ZV (sledovala se návaznost na nižší stupně škol) a katalogy maturitních požadavků (sledovaly se výstupní požadavky na absolventy).

Pokud bychom podrobněji analyzovali scénáře tvorby a výslednou podobu ŠVP na pilotních gymnáziích, nejspíše bychom vypátrali rukopis VÚP. Jednalo se zde totiž o metodicky ř́zenou, resp. asistovanou změnu kurikula, prričemž se $\mathrm{v}$ daném rámci nabízel jistý prostor pro tvořivost jednotlivých škol. Výzvou pro další výzkum je zkoumání scénářù tvorby ŠVP na nepilotních gymnáziích. Bylo by potřebné zjistit, jaká je míra variance ve zpracování týchž pasáží v různých ŠVP. Možná by se tak dalo zjistit, do jaké míry a v jaké podobě se reformní ideje propracovaly do projektovaného kurikula (II), tj. do ŠVP. 


\section{7 ŠVP a realizace výuky}

Při diskusích na toto téma jsou často tematizovány vnitřní rozpory, které přirozeně patří $\mathrm{k}$ výchově: norma vs. volnost, učivo vs. kompetence, spolupráce vs. konkurence atp. Koordinátoři vyjadřovali obavy z formalismu; zdůrazňovali, že vazba kurikulárního programu $\mathrm{s}$ jeho realizací závisí na osobnosti a profesionální kvalitě učitelů. Jako praktický spojovací článek mezi ŠVP a realizací výuky byly zmiňovány tematické plány.

Za tíživý problém bylo pokládáno zvládání proporcí mezi nároky na osvojování učiva a požadavky na rozvíjení klíčových kompetencí žáků. S tím souvisí problém normativity ve vzdělávání: př́lišná volnost vede k oslabení znalostí a ztrátě jednotící úlohy učiva, nadměrná vymezenost hrozí návratem k encyklopedismu.

Tyto problémy zasahují i spolupráci, resp. konkurenci mezi obory ve škole. Jako důvody pro spolupráci $\mathrm{v}$ kurikulu koordinátoři kromě všeobecného vzdělávacího zaměření gymnázií uváděli důraz RVP G na klíčové kompetence, průřezová témata a na vzdělávací oblasti, které sdružují více oborů. Konkurence mezi obory se nejčastěji týkala počtu disponibilních hodin.

Materiální a ekonomické zázemí je podle názorů koordinátorů velmi důležité pro realizaci cílů kurikulární reformy, a tedy i koncepce ŠVP, samo o sobě však nestačí, není-li provázeno pozitivní motivací a profesionálními a osobními kvalitami učitelů.

\subsection{Klíčové kompetence}

Klíčové kompetence $\mathrm{v}$ rozhovorech vystupují jako výzva ke změnám $\mathrm{v}$ profesionálním myšlení a jednání učitelů.

Pojem kompetence vede učitele $\mathrm{k}$ zájmu o náhled na výuku $\mathrm{v}$ podobě analogického posuzování: z kvality průběhu výuky učitel analogicky usuzuje na předpokládanou kvalitu rozvoje žákovských kompetencí. To se projevuje např̀. při hospitacích. Kompetence podle názorů respondentů podporují také spolupráci mezi obory. Koordinátoři popisovali tendenci některých učitelů odmítat pojem kompetence jako cosi velmi vzdáleného, př́liš obecného a obtížně uchopitelného.

Respondenti vyjadřují také obavy z oslabování důrazu na učivo a znalosti pod vlivem důrazu na kompetence, ačkoliv vítají důraz na zvýšenou pestrost metod a lepší motivovanost žáků. Koordinátoři kritizují rozpory mezi nároky na kompetence a na státní maturity. Připisují je nízké úrovni spolupráce mezi institucemi či pracovními skupinami a také objektivní náročnosti celé problematiky kompetencí.

Poukazovalo se také na problémy spojené s profesním jazykem, zejména s formulacemi při snaze propojit jazyk kurikulárních dokumentů s praxí. Také v dalších výzkumech (Janík, 2005) se ukazuje, že mnozí učitelé odmítají odbornou terminologii, k níž se v posledních letech propracovaly oborové didaktiky, pedagogika, pedagogická psychologie a další vědy o výchově. Zdá se, že v osvojení odborného jazyka není shledáván potenciál pro hlubší porozumění podstatě procesů vyučování, učení apod.

Domníváme se, že v tomto ohledu máme co do činění s velmi závažnou deprofesionalizační tendencí. Východiskem z této situace by mohl být připravovaný Standard profese učitelství, jenž by k profesionalizaci směřoval na základě zvyšování odborných nárokủ kladených na učitele, a to zejména $v$ jejich př́ípravném a dalším vzdělávání. 


\subsection{Autoevaluace a evaluace}

Evaluace včetně autoevaluace jsou zpětnovazebním a korektivním prostředkem podpory pro hlavní principy reformy a slouží k tomu, ,aby škola byla zdravá“, jak zaznělo v rozhovorech. Spolu s kompetencemi je evaluace a autoevaluace koordinátory pokládána za jeden $\mathrm{z}$ klíčových a současně náročných momentů reformy. Má to oprávnění $\mathrm{s}$ ohledem na zpětnovazební úlohu (auto)evaluace, která od učitelů vyžaduje pojmově uchopit reflexi své praxe, a tak lépe porozumět výuce a potřebám žáků.

Koordinátoři v rozhovorech konstatují, že autoevaluace běžně patř́ k pedagogické práci, ale připouštějí své potíže s jejím pojmovým uchopením v souvislosti s terminologií kurikulárních dokumenti̊. Zaznívají např. pochybnosti, do jaké míry a zda vůbec lze měřit kompetence.

V praxi se však školy evaluací soustředěně zabývají a hledají její nejlepší způsoby. Koordinátoři vyzdvihují, že kvalitní (auto)evaluace vyžaduje vysoce odbornou př́pravu a kritizují v tomto ohledu nedostatečnost dalšího vzdělávání učitelů. Kritizují také nedostatek obecně použitelných metodických nástrojů pro evaluaci a $\mathrm{v}$ této souvislosti vyjadřují nespokojenost $\mathrm{s}$ podporou ze strany ČŠI. V rozhovorech jsou také důrazně kritizovány nedostatky $\mathrm{v}$ přípravě státních maturit, které by měly poskytnout zastřešení pro evaluaci výuky.

V systémovém pohledu na kurikulární reformu by evaluace měla být chápána jako nástroj zpětné vazby a korekce. Půjde o to, do jaké míry se v našem systému podaří nastavit „zdravé evaluační prostředí, v němž se vedle možnosti pozitivního hodnocení otevře také prostor pro kritiku.

\section{Závěrem}

Kurikulární reformu provází zcela přirozeně řada otevřených otázek, které je třeba průběžně vysvětlovat. $K$ tomu budou směřovat mj. naše další výzkumy. Jejich cílem je přinést spolehlivé poznatky o tom, jak jsou př́nosy a problémy kurikulární reformy vnímány na ostatních, tj. nepilotních gymnáziích v České republice. $Z$ předběžných výsledků našich výzkumu zatím víme, že na gymnáziích panuje značný neklid a nespokojenost s vývojem a stavem školství obecně a gymnaziálního vzdělávání obzvlášt'.

Je dost dobře možné, že školy interpretují jakékoliv reformní snahy jako principiální vyjádření nedůvěry v jejich dosavadní práci. V jednom rozhovoru k tomu zaznělo: „Myšlenka reformy může znejišt'ovat učitele v tom, že si do ted' mysleli, že to dělali dobře, a ted' po nich někdo chce radikální změnu“. A tak se z reformy stává poměrně citlivý problém související s profesní a osobní identitou učitele. Bylo by tudíž zapotřebí investovat především do jeho osoby a nemám tím na mysli pouze investice finanční povahy...

\section{Literatura}

Altrichter, H. (2009). Governance - Schulreform als Handlungskoordination. Die Deutsche Schule, 101(3), 240-252.

Altrichter, H., \& Wiesinger, S. (2005). Implementation von Schulinnovationen - aktuelle Hoffnungen und Forschungswissen. Journal für Schulentwicklung, 9(4), 28-36.

Janík, T. (2005). Znalost jako klíčová kategorie učitelského vzdélávání. Brno: Paido.

Janík, T., Janko, T., Knecht, P., Kubiatko, M., Najvar, P., Pavlas, T., Slavík, J., Solnička, D., \& Vlčková, K. (2010b). Kurikulární reforma na gymnáziich: výsledky dotazníkového šetření. Praha: Výzkumný ústav pedagogický v Praze. 
Janík, T., Knecht, P., Kubiatko, M., Pavlas, T., Slavík, J., Solnička, D., \& Vlček, P. (2011). Kvalita školy a kurikula: od expertniho šetřeni ke standardu. Praha: Výzkumný ústav pedagogický v Praze.

Janík, T., Knecht, P., Najvar, P., Pavlas, T., Slavík, J., \& Solnička, D. (2010a ). Kurikulární reforma na gymnáziích v rozhovorech s koordinátory pilotnich a partnerských škol. Praha: Výzkumný ústav pedagogický v Praze.

Janík, T., Najvar, P., \& Solnička, D. (2011). Od idejí k implementaci: kurikulární reforma v rozhovorech s řediteli (nepilotních) gymnázií. Orbis Scholae, 5(3), (v tisku).

Janík, T., Slavík, J., Najvar, P., Hajdušová, L., Hesová, A., Lukavský, J., Minaříková, E., Píšová, M., \& Švecová, Z. (2011). Kurikulárni reforma na gymnáziích: od virtuálnich hospitací $k$ videostudiím. Praha: Výzkumný ústav pedagogický v Praze.

Kotásek, J. (1993). Pedagogický výzkum a transformace vzdělávací soustavy. Pedagogika, 43(4), 363-369.

Lazarová, B. (2005). Psychologické aspekty profesionálního rozvoje učitelů: rezistence vůči změně. Pedagogika, 45(2), 102-118.

Píšová, M., Kostková, K., Janík, T., Doulík, P., Hajdušková, L., Knecht, P., Lukavský, J., Najvar, P., Najvarová, V., Maňák, J., Pavlas, T., Slavík, J., Spurná, M., Stehlíková, N., Škoda, J., \& Vlček, P. (2011). Kurikulárni reforma na gymnáziich. Př́ipadové studie tvorby kurikula. Praha: Výzkumný ústav pedagogický v Praze.

Pupala, B. (2008). Mocenské putá reformy. Pedagogika, 58(4), 311-314.

Slavík, J., \& Chvál, M. (2008). Metodologické otázky výzkumu. In V Spilková, \& J. Vašutová et al. Učitelská profese v ménícich se požadavcích na vzdělávání (pp. 51-62). Praha: PedF UK.

Straková, J. (2007). Kurikulární reforma z pohledu šetření Kalibro. Pedagogika, 57(1), 21-36.

Terhart, E. (2002). Nach PISA: Bildungsqualität entwickeln. Hamburg: Europäische Verlagsanstalt.

Walterová, E., Černý, K., Greger, D., \& Chvál, M. (2010). Školství - věc (ne)veřejná? Názory veřejnosti na školu a vzdělávání. Praha: Karolinum.

\section{Kontakt}

doc. PhDr. Tomáš Janík, Ph.D., M.Ed.

Mgr. Petr Knecht, Ph.D.

Mgr. David Solnička

Masarykova univerzita

Pedagogická fakulta, Institut výzkumu školního vzdělávání

Poříčí 31, 60300 Brno

e-mail: tjanik@ped.muni.cz

knecht@ped.muni.cz

136126@mail.muni.cz

\section{Bibliografické údaje}

Janík, T, Knecht, P., \& Solnička, S. (2011). Kurikulání reforma na gymnáziích: rozhovory s koordinátory. In T. Janík, P. Knecht, \& S. Šebestová (Eds.), Smíšený design v pedagogickém výzkumu: Sbornik přispěvki̊ z 19. výročni konference České asociace pedagogického výzkumu (s. 716). Brno: Masarykova univerzita.

Dostupné z: http://www.ped.muni.cz/capv2011/sbornikprispevku/janikknechtsolnicka.pdf doi: 10.5817/PdF.P210-CAPV-2012-15 